Article

\title{
Biomimetic preparation of organic-inorganic composite microcapsules for glucose oxidase immobilization
}

\author{
Qian Xin a, Yanjun Jiang a,b,*, Jing Gao a,\#, Liya Zhou a, Li Ma a , Ying He a, Fei Jia ${ }^{\text {a }}$ \\ a School of Chemical Engineering, Hebei University of Technology, Tianjin 300130, China \\ ${ }^{\mathrm{b}}$ National Key Laboratory of Biochemical Engineering, Institute of Process Engineering, Chinese Academy of Sciences, Beijing 100190, China
}

\section{A R T I C L E I N F O}

\section{Article history:}

Received 25 March 2013

Accepted 19 June 2013

Published 20 August 2013

Keywords:

Composite microcapsule

Layer-by-layer assembly

Biomimetic mineralization

Glucose oxidase

\begin{abstract}
A B S T R A C T
Organic-inorganic composite microcapsules made of sodium poly(styrenesulfonate) (PSS), poly(dimethyl diallyl ammonium chloride) (PDADMAC), and biomimetic silica were successfully fabricated via a combination of layer-by-layer self-assembly and biomimetic mineralization. The morphologies and chemical compositions of the microcapsules (denoted by (PSS/PDADMAC) ${ }_{2}-\mathrm{SiO}_{2}$ ) were characterized using scanning electron microscopy, Fourier-transform infrared spectroscopy, and thermogravimetric analysis. The composite microcapsules were used as carrier for the immobilization of glucose oxidase (GOD). GOD encapsulated in (PSS/PDADMAC) ${ }_{2}-\mathrm{SiO}_{2}$ (denoted by GOD@(PSS/PDADMAC) $)_{2}-\mathrm{SiO}_{2}$ ) displayed improved thermal, $\mathrm{pH}$, and operational stabilities. The activity recovery of the immobilized GOD reached $72.85 \%$ under the optimized conditions. GOD@(PSS/PDADMAC) $)_{2}-\mathrm{SiO}_{2}$ showed a 2.21-fold increase in the Michaelis constant $\left(K_{\mathrm{m}}\right)$ compared with free GOD. The composite microcapsules have the potential for a range of applications in chemical/biological catalysis and drug/gene delivery systems, and as biosensors.
\end{abstract}

(C) 2013, Dalian Institute of Chemical Physics, Chinese Academy of Sciences. Published by Elsevier B.V. All rights reserved.

\section{Introduction}

Micro-sized polyelectrolyte capsules, which are prepared using layer-by-layer (LbL) self-assembly, have emerged as attractive materials in the fields of enzyme immobilization and controlled drug delivery [1]. These microcapsules can be produced from a wide variety of building blocks and have promising features such as ultra-thin walls and ease of functionalization as a result of the chelating effect of charged groups [2,3]. Enzymes encapsulated in these microcapsules are in a non-complexed state (i.e., in the free form) and exhibit high activity and reusability [4]. Various enzymes have therefore been incorporated into the cavities of microcapsules. Com- pared with polyelectrolyte capsules, organic-inorganic composite microcapsules often have excellent properties such as superior physicochemical and mechanical stabilities and high resistance to organic solvents. Substituting the organic shell by an organic-inorganic composite can therefore significantly increase the microcapsule functionality, and such microcapsules potentially have wide applications in catalysis, energy, and medicine [5-7]. However, several problems encountered in preparing composite microcapsules, such as separate preparation of the inorganic nanoparticles prior to electrostatic adsorption and difficulties associated with optimization of the solution conditions, need to be overcome [5-13].

Recently, a novel approach to prepare organic-inorganic

\footnotetext{
*Corresponding author. Tel/Fax: +86-22-60204945; E-mail: yanjunjiang@hebut.edu.cn

\# Corresponding author. Tel/Fax: +86-22-60204293; E-mail: jgao@hebut.edu.cn

This work was supported by the National Natural Science Foundation of China (21006020, 21276060, 21276062), the Application Basic Research Plan Key Basic Research Project of Hebei Province (11965150D), the Natural Science Foundation of Tianjin (13JCYBJC18500), and the Open Funding Project of the National Key Laboratory of Biochemical Engineering (China).

DOI: 10.1016/S1872-2067(12)60635-4 | http://www.sciencedirect.com/science/journal/18722067| Chin. J. Catal., Vol. 34, No. 8, August 2013
} 
composite microcapsules, combining LbL self-assembly and biomimetic mineralization, was proposed by Jiang et al. [11]. Biomimetic mineralization, which mimics the natural process, uses biological molecules to template the formation of inorganic materials under ambient conditions [14-17]. More specifically, these composite microcapsules were fabricated by alternating deposition of positively charged polyelectrolyte layers and negatively charged polyelectrolyte layers on the surfaces of $\mathrm{CaCO}_{3}$ microparticles. Then the inorganic layer was constructed through a biomimetic mineralization process induced by the positively charged polyelectrolyte layer, followed by removal of the $\mathrm{CaCO}_{3}$ microparticles. The as-prepared microcapsules were used to immobilize enzymes and the encapsulated enzymes showed considerably enhanced stabilities [12]. The combination of LbL self-assembly and biomimetic mineralization can therefore be regarded as a versatile bottom-up nanofabrication technique for preparing composite microcapsules [3]. Jiang et al. [11] also used this technique to develop a capsules-in-bead microreactor comprising silica-based composite microcapsules to construct a spatially separated multienzyme cascade system, which demonstrated the exciting potential of multienzyme catalysis applications; however, more extensive exploitation is still required.

In recent years, an approach combining LbL self-assembly with biomimetic mineralization has been used to prepare a variety of organic-inorganic composite materials. For example, Sandhage and his coworkers [18] used this approach to prepare freestanding microscale titania structures, whose morphologies were derived from complex-shaped, three-dimensional biosilica templates (diatom frustules). Freestanding, aligned, porous-wall titania nanotube arrays were also prepared by this process. They also described a method for enzyme immobilization in conformal mineral nanocoatings using this method [19]. Jan et al. [20] applied this approach to the synthesis of polypeptide/silica and polypeptide/gold nanoparticle/silica composite materials. Hybrid double-membrane microcapsules (HDMMCs) with mitochondria-like structures were also constructed through synergy between biomimetic mineralization and LbL self-assembly using a double-templateing strategy. The HDMMCs were used to construct a multienzyme system, and the enzymatic activity, selectivity, and recycling stability of the multienzyme system were significantly better than those of encapsulated multienzymes in single-compartment microcapsules or in the free form [21].

Glucose oxidase (GOD), a dimeric enzyme with a molecular weight of $160 \mathrm{kDa}$, is commonly used in biosensors and biocatalysis. Many methods have been used to immobilize GOD [22-25]. However, to the best of our knowledge, there has been no report of GOD immobilization using a combination of LbL self-assembly and biomimetic mineralization. In the current study, (PSS/PDADMAC) ${ }_{n}-\mathrm{SiO}_{2}$ microcapsules were fabricated using a combination of LbL assembly and biomimetic silicification. PDADMAC, which is positively charged, and PSS, which is negatively charged, were alternately deposited onto $\mathrm{CaCO}_{3}$ templates. An inorganic silica layer was then fabricated via biomimetic silicification induced by the outer PDADMAC layer. The PDADMAC layer served not only as the "electrostatic glue" for LbL assembly, but also as a catalyst for formation of the silica layer [26]. The prepared microcapsules were characterized using Fourier-transform infrared spectroscopy (FT-IR), thermogravimetric analysis (TGA), and scanning electron microscopy (SEM). These microcapsules were employed to immobilize GOD. The thermal, $\mathrm{pH}$, and reusabilities of the encapsulated GOD were investigated. Finally, the Michaelis constant $\left(K_{\mathrm{m}}\right)$ and the maximal velocity $\left(V_{\max }\right)$ values of free and encapsulated GOD were measured.

\section{Experimental}

\subsection{Preparation of microcapsules and enzyme immobilization}

PSS (20 wt\%), PDADMAC, GOD, and horse radish peroxidase (HRP) were purchased from Sigma-Aldrich. All reagents were of analytical grade and used without further purification.

$\mathrm{CaCO}_{3}$ microparticles were prepared as follows. First, PSS (300 mg) was added to $10 \mathrm{ml}$ of $\mathrm{CaCl}_{2} \cdot 2 \mathrm{H}_{2} \mathrm{O}$ solution $(0.33$ mol/L). Next, $10 \mathrm{ml}$ of $\mathrm{Na}_{2} \mathrm{CO}_{3}$ solution $(0.33 \mathrm{~mol} / \mathrm{L})$ were rapidly added to the mixture. After vigorous agitation for $20 \mathrm{~s}$, the reaction mixture was left for 20 min to allow transformation of the amorphous primary $\mathrm{CaCO}_{3}$ precipitate to spherical microparticles. The resultant $\mathrm{CaCO}_{3}$ microparticles were centrifuged and thoroughly washed with water. The enzyme-loaded $\mathrm{CaCO}_{3}$ microparticles were prepared using a coprecipitation procedure. First, GOD (2 mg) and PSS (300 mg) were added to $10 \mathrm{ml}$ of $\mathrm{CaCl}_{2} \cdot 2 \mathrm{H}_{2} \mathrm{O}$ solution ( $\left.0.33 \mathrm{~mol} / \mathrm{L}\right) . \mathrm{CaCO}_{3}$ microparticles with GOD were then prepared using the procedure described above.

In the preparation of the (PSS/PDADMAC) $n$ microcapsules, the prepared $\mathrm{CaCO}_{3}$ microparticles were dispersed in PSS solution ( $5 \mathrm{mg} / \mathrm{ml}, \mathrm{pH} 7.0)$ containing $\mathrm{NaCl}(0.5 \mathrm{~mol} / \mathrm{L})$ under mild shaking. After shaking for $15 \mathrm{~min}$, the $\mathrm{CaCO}_{3}$ microparticles coated with PSS were collected by centrifugation and washed three times with water to remove residual PSS. These microparticles were then suspended in PDADMAC solution $(2 \mathrm{mg} / \mathrm{ml}$, $\mathrm{pH} 7.0)$ containing $\mathrm{NaCl}(0.5 \mathrm{~mol} / \mathrm{L})$ for $15 \mathrm{~min}$ under mild shaking. After centrifugation and washing three times with water, $\mathrm{CaCO}_{3}$ microparticles coated with one PSS layer and one PDADMAC layer were obtained. This procedure was repeated until the desired number of layers had been deposited. The (PSS/PDADMAC $)_{n}$ microparticles were obtained after removal of $\mathrm{CaCO}_{3}$ by incubating the microparticles in $\mathrm{HCl}$ solution $(0.02$ $\mathrm{mol} / \mathrm{L})$.

Hydrolyzed tetramethyl orthosilicate (TMOS) was used as the silica precursor for the preparation of (PSS/PDADMAC) $n^{-}$ $\mathrm{SiO}_{2}$. (PSS/PDADMAC) $n$ microparticles with an outer layer of PDADMAC were incubated in hydrolyzed TMOS solution $(0.03$ $\mathrm{mol} / \mathrm{L}, \mathrm{pH}$ 7.0) for $15 \mathrm{~min}$, followed by centrifugation, washing, and removal of $\mathrm{CaCO}_{3}$.

The (PSS/PDADMAC) $n$ and (PSS/PDADMAC) ${ }_{n}-\mathrm{SiO}_{2}$ for enzyme encapsulation were prepared using the above enzyme-loaded $\mathrm{CaCO}_{3}$ microparticles.

To examine the leakage of GOD from the microcapsules, GOD-encapsulated microcapsules with different numbers of bilayers were added to $5 \mathrm{ml}$ of Tris- $\mathrm{HCl}$ buffer solution $(0.05$ mol/L, pH 7.0) and incubated for a period of time at room 
temperature. The mixture was then centrifuged, and the GOD content of the supernatant was determined by the micro-Bradford method [27] using an ultraviolet (UV) spectrophotometer (UV-1600, Mapada, Shanghai, China). The microcapsules were resuspended in $5 \mathrm{ml}$ of fresh buffer solution, and the procedure described above was repeated. The GOD leakage was defined as the ratio of the cumulative amount of GOD leaked to the initial amount of immobilized GOD.

\subsection{Characterization}

For SEM images, samples were prepared by dropping a microcapsule suspension onto a clean glass slide, air drying, and sputtering with gold. The images were obtained using a JEOL JSM-6700F (Japan) instrument. FT-IR spectra of the microcapsules were obtained using a Bruker Vector-22 (Germany) spectrometer. TGA using a NETZSCH STA 409 PC/PG analyzer (Germany) was performed to confirm the contents and decomposition behavior of the microcapsules. The temperature was increased from 34 to $800{ }^{\circ} \mathrm{C}$ at a rate of $10{ }^{\circ} \mathrm{C} / \mathrm{min}$, and data were collected in an air atmosphere.

\subsection{Determination of GOD activity and stability}

A colorimetric method based on Trinder's reaction was used for the determination of GOD activity and stability [1]. The GOD activity unit (U) was defined as 0.001 changes in absorbance per second at $25^{\circ} \mathrm{C}$ (the highest activity was taken as $100 \%$ ). Briefly, free and encapsulated GOD were allowed to react with $1.5 \mathrm{ml}$ of $\mathrm{A}$ and $1.5 \mathrm{ml}$ of $\mathrm{B}$ for $2 \mathrm{~min}$, where A was a mixture of HRP (3.5 mg), 4-aminoantipyridine (4-AAP, $3.5 \mathrm{mg}$ ), phosphate buffer solution (PBS, $0.2 \mathrm{~mol} / \mathrm{L}, 20 \mathrm{ml}, \mathrm{pH}$ 7.0), and phenol (3 $w t \%, 1 \mathrm{ml}$ ), and $\mathrm{B}$ was a glucose solution (13 wt\%). $\mathrm{H}_{2} \mathrm{O}_{2}$ was generated in situ by the reaction of glucose with air, using GOD reacted with phenol and 4-AAP, catalyzed by HRP. The colored product formed during the reaction was detected using UV spectroscopy at $500 \mathrm{~nm}$, and the activity of the enzyme was then calculated.

The thermal and $\mathrm{pH}$ stabilities were determined by measuring the activities of GOD exposed to different temperatures (25-60 ${ }^{\circ} \mathrm{C}$ ) and PBS (pH 4.0-8.0) for $1.5 \mathrm{~h}$.

The operational stabilities of the encapsulated GOD were tested by measuring the enzyme activity in each successive reaction cycle and were expressed as the recycling operational stability. The encapsulated GOD was allowed to react with 1.5 $\mathrm{ml}$ of $\mathrm{A}$ and $1.5 \mathrm{ml}$ of $\mathrm{B}$ for $2 \mathrm{~min}$ at the optimum $\mathrm{pH}$ and temperature. The encapsulated GOD was filtered off and rinsed with distilled water, and then redispersed in fresh reaction medium for the next reaction cycle. The process was repeated six times. The relative operational stability was calculated by (residual enzyme activity in the $n$th cycle)/(enzyme activity in the first cycle) $\times 100 \%$.

Free and encapsulated GOD were stored at $4{ }^{\circ} \mathrm{C}$ for $33 \mathrm{~d}$. Every third day, the activities of free and encapsulated GOD were measured. The relative storage stability was calculated by (residual enzyme activity after $n$ days)/(initial enzyme activity) $\times 100 \%$.
$K_{\mathrm{m}}$ and $V_{\max }$ were determined at the optimum $\mathrm{pH}$ and $25{ }^{\circ} \mathrm{C}$ using the Michaelis-Menten model. To determine the $K_{\mathrm{m}}$ and $V_{\max }$ values, the activity assay was applied to different glucose concentrations (0.0056-0.05 mmol/L), and the activities of free and encapsulated GOD were then measured. The kinetic parameters for both free and the immobilized GOD were calculated accordingly.

\section{Results and discussion}

\subsection{Structures and properties of the organic-inorganic composite microcapsules}

FT-IR spectra of the microcapsules are shown in Fig. 1. The vibration bands at 3439,1646 , and $1473 \mathrm{~cm}^{-1}$ were ascribed to vibrations of the amino group of PDADMAC. The absorption bands at $1183 \mathrm{~cm}^{-1}$ (S=0 asymmetric stretching) and 1040 $\mathrm{cm}^{-1}$ ( $\mathrm{S}=0$ symmetric stretching) were the characteristic bands of PSS. Unlike (PSS/PDADMAC)2, the FT-IR spectrum of (PSS/PDADMAC) $)_{2}-\mathrm{SiO}_{2}$ clearly shows a peak at $1090 \mathrm{~cm}^{-1}$, which was attributed to $\mathrm{Si}-\mathrm{O}-\mathrm{Si}$ band [28].

The TGA curves of the microcapsules are shown in Fig. 2. The small weight loss of the samples with increasing temperature from 30 to $120^{\circ} \mathrm{C}$ was attributed to moisture evaporation. A rapid weight loss was then observed in the range $250-800^{\circ} \mathrm{C}$,

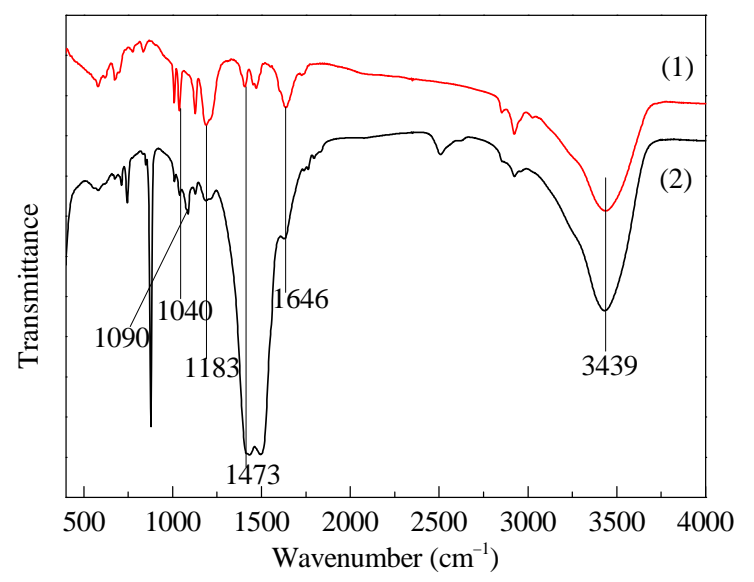

Fig. 1. FT-IR spectra of microcapsules. (1) (PSS/PDADMAC) 2 ; (2) (PSS/PDADMAC) ${ }_{2}-\mathrm{SiO}_{2}$.

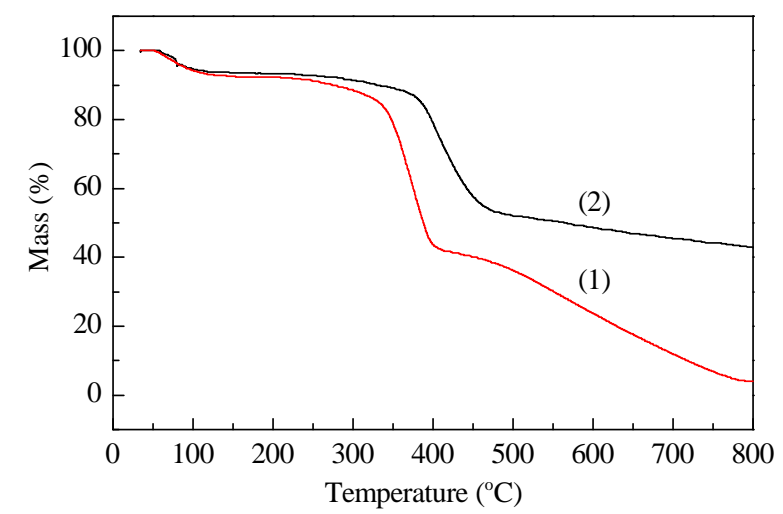

Fig. 2. TGA curves of microcapsules. (1) (PSS/PDADMAC) 2 ; (2) (PSS/PDADMAC) $2-\mathrm{SiO}_{2}$. 


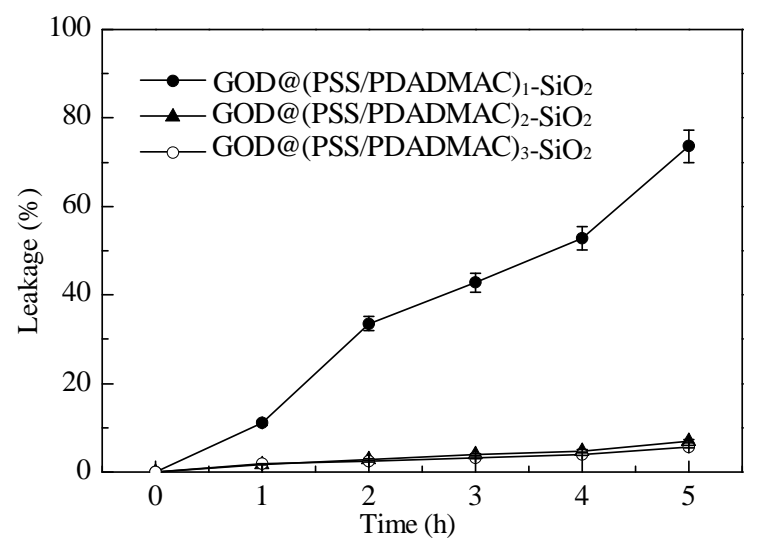

Fig. 3. GOD leakage from GOD@(PSS/PDADMAC ${ }_{n}-\mathrm{SiO}_{2}(n=1,2,3)$

which can be ascribed to oxidation of PSS and PDADMAC. In the TGA curve of (PSS/PDADMAC) $2-\mathrm{SiO}_{2}$, a $55 \%$ weight loss was observed from 250 to $800{ }^{\circ} \mathrm{C}$. However, a $100 \%$ weight loss was observed at $800{ }^{\circ} \mathrm{C}$ in the TGA trace of (PSS/PDADMAC) 2 . These results demonstrated the formation of silica in the shell of the composite microcapsules.

The GOD leakage profiles for (PSS/PDADMAC) ${ }_{n}-\mathrm{SiO}_{2}$ microcapsules with different numbers of layers were examined and compared, as shown in Fig. 3. About 73.6\% of GOD leaked out of (PSS/PDADMAC) ${ }_{1}-\mathrm{SiO}_{2}$ within $5 \mathrm{~h}$, whereas about $6.9 \%$ and $5.7 \%$ of GOD leaked out of (PSS/PDADMAC) $)_{2}-\mathrm{SiO}_{2}$ and (PSS/ PDADMAC) $)_{3}-\mathrm{SiO}_{2}$, respectively, within $5 \mathrm{~h}$. As can be seen, as the layer number increased, GOD leakage decreased. The microcapsule permeability can therefore be readily tuned using the layer number. Although the leakage rate for (PSS/PDADMAC) ${ }_{3}-\mathrm{SiO}_{2}$ was lower than that for (PSS/PDADMAC) $)_{2}-\mathrm{SiO}_{2}$, the (PSS/PDADMAC) $3-\mathrm{SiO}_{2}$ preparation process was complex and the mass-transfer resistance was higher, so (PSS/PDADMAC) $2-\mathrm{SiO}_{2}$ was chosen as the ideal carrier.

SEM images of (PSS/PDADMA) 2 and (PSS/PDADMA) $)_{2}-\mathrm{SiO}_{2}$ are shown in Fig. 4. The (PSS/PDADMA)2 morphology after drying had folds and creases, suggesting a hollow structure and low mechanical strength of the capsule wall. However, (PSS/PDADMAC) $2-\mathrm{SiO}_{2}$ kept a regular spherical shape. Their diameters were around $3 \mu \mathrm{m}$. These results indicated that the shell of (PSS/PDADMAC) $)_{2}-\mathrm{SiO}_{2}$ had strong mechanical strength, which could be attributed to the formation of silica layers. In contrast, (PSS/PDADMAC) 2 microcapsules composed of organic

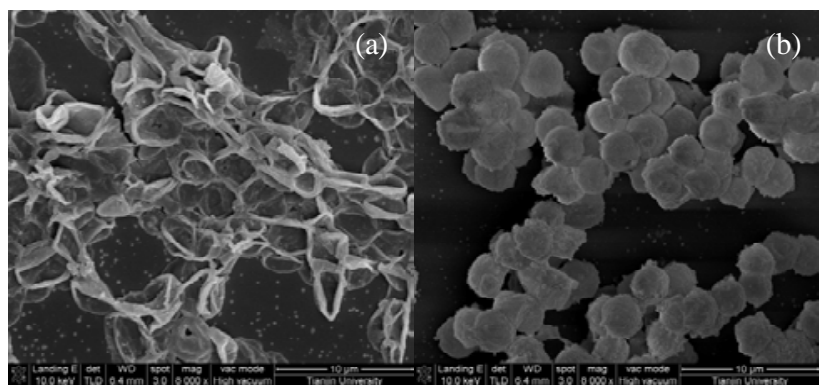

Fig. 4. SEM images of microcapsules. (a) (PSS/PDADMAC)2; (b) (PSS/PDADMAC) $)_{2}-\mathrm{SiO}_{2}$. polyelectrolytes often collapsed after drying as a result of their weak mechanical strength. (PSS/PDADMAC) $2-\mathrm{SiO}_{2}$ may therefore be better than (PSS/PDADMAC) 2 for applications in enzyme immobilization and drug delivery [14].

\subsection{Stability of free and encapsulated GOD}

Figure 5 shows that the highest activity of free GOD, GOD@(PSS/PDADMAC)2, and GOD@(PSS/PDADMAC)2-SiO were all $238.60 \mathrm{U}$. The highest activity was taken as $100 \%$. In Fig. 5(a), it can be seen that free GOD, GOD@(PSS/PDADMAC)2, and GOD@(PSS/PDADMAC) ${ }_{2}-\mathrm{SiO}_{2}$ showed maximum activities at $\mathrm{pH}$ 5.5. At $\mathrm{pH} 4.0$, the two types of encapsulated GOD retained more than $50 \%$ of their initial activities. When the $\mathrm{pH}$ was switched from 5.0 to 8.0, GOD@(PSS/PDADMAC)2-SiO 2 retained about $70 \%$ of its initial activity, which was higher than that retained by GOD@(PSS/PDADMAC)2. However, its soluble counterpart retained about $40 \%$ of its original activity at $\mathrm{pH} 8.0$ and about $43 \%$ at $\mathrm{pH} 4.0$. The resistance of the encapsulated enzyme against changes in the acidity and alkalinity of the medium was tentatively explained by the buffering effect of the interior PDADMAC layer. PDADMAC is a weak polyelectrolyte and positively charged under the $\mathrm{pH}$ test conditions, so it could tune the local $\mathrm{pH}$ to some extent if the bulk $\mathrm{pH}$ changed, as a result of abundant $=\mathrm{NH} /=\mathrm{NH}_{2}{ }^{+}$and $-\mathrm{NH}_{2} /-\mathrm{NH}_{3}{ }^{+}$pairs (a buffering effect). The $\mathrm{pH}$ change in the capsule microenvironment was therefore thought to be smaller than that in the bulk solution. Besides dissociation of protons from the amino groups, at high $\mathrm{pH}$, the residual silanol $(\mathrm{Si}-\mathrm{OH})$ groups could dissociate into $\mathrm{Si}-\mathrm{O}^{-}$species [29]. GOD@(PSS/PDADMAC)2-SiO 2 therefore retained more initial activity at high $\mathrm{pH}$.

It can be seen from Fig. 5(b) that when the temperature reached $60{ }^{\circ} \mathrm{C}$, for GOD@(PSS/PDADMAC) $2-\mathrm{SiO}_{2}, 60 \%$ of the initial activity was still retained, whereas GOD@(PSS/PDADMAC) 2 and free GOD retained 53\% and 50\%, respectively, of their initial activities. The results showed that a high temperature had more significant effects on free GOD and GOD@(PSS/PDADMAC)2.

Operational stability is a critical issue for immobilized enzymes. Figure 5(c) shows that GOD@(PSS/PDADMAC) $)_{2}-\mathrm{SiO}_{2}$ retained about $82 \%$ of its initial activity after recycling six times. However, GOD@(PSS/PDADMAC)2 retained about 49\% of its initial activity after recycling six times. The high operational stability of (PSS/PDADMAC) $)_{2}-\mathrm{SiO}_{2}$ could be attributed to its inorganic shell, which played a very important role in protecting GOD from leaching.

Figure 5(d) shows that the storage stabilities of the free and encapsulated GOD were similar after storage for $33 \mathrm{~d}$; they retained about $70 \%$ of their initial activities. Loss of enzyme activity during storage is usually the result of protein degradation by microbes [14].

From all the above results, it was reasonable to believe that GOD@(PSS/PDADMAC) $2-\mathrm{SiO}_{2}$ microcapsules exhibited good adaptability to harsh conditions because they provided suitable microenvironments for the encapsulated enzymes. GOD@(PSS/PDADMAC) $2-\mathrm{SiO}_{2}$ showed higher tolerance and stability than free GOD and GOD@(PSS/PDADMAC)2. 

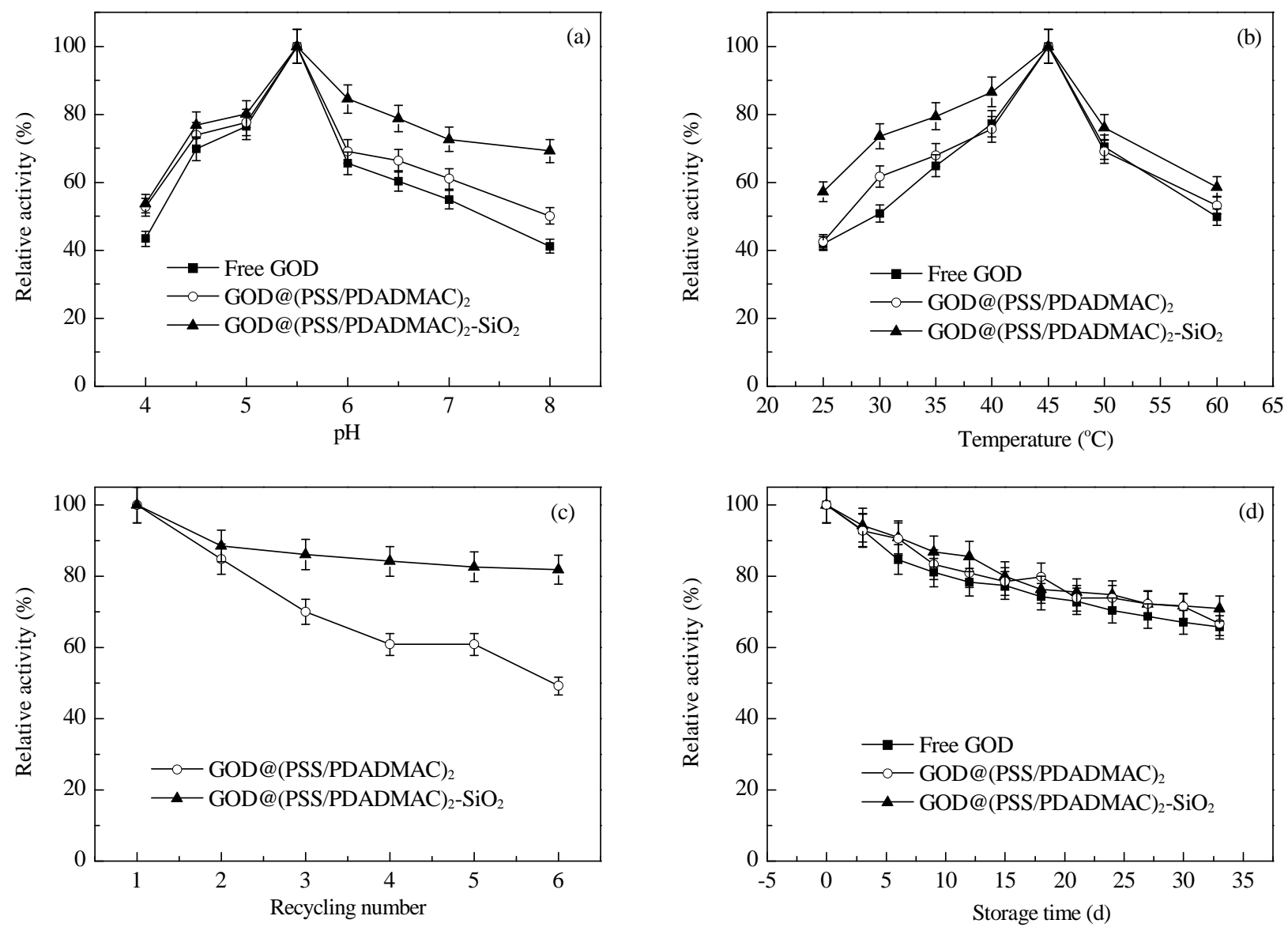

Fig. 5. Relative activities of free and encapsulated GOD at different pH (a) and temperature (b), and operational stabilities (c) and storage stabilities (d) of free and encapsulated GOD.

\subsection{Kinetic studies of free and encapsulated GOD}

The effect of immobilization on the kinetic parameters was studied by measuring the initial reaction rates of the consumption of glucose catalyzed by free and encapsulated GOD at various glucose concentrations [30]. The Lineweaver-Burk plots for free and encapsulated GOD are shown in Fig. 6. The $K_{\mathrm{m}}$ and $V_{\max }$ values were calculated from the slopes and intercepts, respectively, of the straight lines.

The data in Table 1 show that $K_{\mathrm{m}}$ of the immobilized GOD was higher, and $V_{\max }$ was lower, than those of free GOD. The $K_{\mathrm{m}}$ indicates the affinity of an enzyme with a substrate, and a lower value of $K_{\mathrm{m}}$ means a higher affinity between an enzyme and a substrate [31]. The increase in $K_{\mathrm{m}}$ after immobilization indicated weaker binding between the glucose molecules and the immobilized GOD. The decreased $V_{\max }$ of the immobilized GOD could be caused by additional diffusion limitation to the substrate (glucose) and the product $\left(\mathrm{H}_{2} \mathrm{O}_{2}\right)$, caused by the layers of the microcapsule, resulting in low accessibility of the substrate to the active sites of GOD, consequently resulting in a lower possibility of enzyme-substrate complex formation. In addition, the $K_{\mathrm{m}}$ of GOD@(PSS/PDADMAC) $2-\mathrm{SiO}_{2}$ was higher than that of GOD@(PSS/PDADMAC)2, but the $V_{\max }$ of the former was lower, which are attributed to the additional diffusion resistance caused by the inorganic shell, as shown in Table 1.

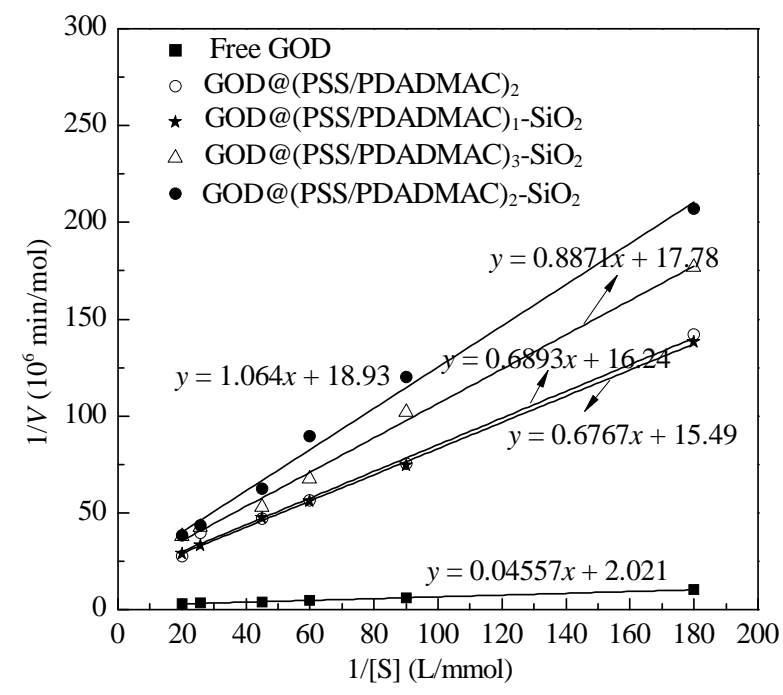

Fig. 6. Lineweaver-Burk plots for free and encapsulated GOD.

Table 1

Kinetic parameters for free and encapsulated GOD.

\begin{tabular}{|c|c|c|}
\hline GOD & $K_{\mathrm{m}}\left(\mathrm{mmol} \mathrm{L}^{-1}\right)$ & $V_{\max }\left(\mathrm{mol} \mathrm{min}^{-1}\right)$ \\
\hline Free GOD & 22.55 & 0.4948 \\
\hline GOD@(PSS/PDADMAC) $)_{2}$ & 42.45 & 0.06158 \\
\hline GOD@(PSS/PDADMAC) ${ }_{1}-\mathrm{SiO}_{2}$ & 43.68 & 0.06454 \\
\hline GOD@(PSS/PDADMAC) ${ }_{2}-\mathrm{SiO}_{2}$ & 49.88 & 0.05623 \\
\hline GOD@(PSS/PDADMAC) ${ }_{3}-\mathrm{SiO}_{2}$ & 56.21 & 0.05282 \\
\hline
\end{tabular}




\section{Conclusions}

GOD was successfully immobilized in organic-inorganic composite microcapsules using a combination of layer-by-layer (LbL) assembly and biomimetic mineralization. The LbL self-assembly and biomimetic mineralization took place under mild reaction conditions and provided an excellent support for enzyme immobilization. Compared with free GOD and GOD@(PSS/PDADMAC)2, GOD@(PSS/PDADMAC)2-SiO 2 was better at enhancing enzyme stability against changes in temperature and $\mathrm{pH}$, and during long-term storage. These organic-inorganic composite microcapsules will be useful in applications such as chemical/biological catalysis and drug/gene controlled release.

\section{References}

[1] De Temmerman M L, Demeester J, De Vos F, De Smedt S C. Biomacromolecules, 2011, 12: 1283

[2] Sukhorukov G B, Donath E, Lichtenfeld H, Knippel E, Knippel M, Budde A, Möhwald H. Colloids Surf A, 1998, 137: 253

[3] Ariga K, Hill J P, Ji Q M. Phys Chem Chem Phys, 2007, 9: 2319

[4] Volodkin D V, Larionova N I, Sukhorukov G B. Biomacromolecules, 2004, 5: 1962

[5] Pouget E, Dujardin E, Cavalier A, Moreac A, Valery C, Marchi-Artzner V, Weiss T, Renault A, Paternostre M, Artzner F. Nat Mater, 2007, 6: 434

[6] Söllner C, Burghammer M, Busch-Nentwich E, Berger I, Schwarz H, Riekel C, Nicolson T. Science, 2003, 302: 282

[7] Aizenberg J, Weaver J C, Thanawala M S, Sundar V C, Morse D E, Fratzl P. Science, 2005, 309: 275

[8] Yu J, Murthy V S, Rana R K, Wong M S. Chem Commun, 2006: 1097

[9] Murthy V S, Kadali S B, Wong M S. ACS Appl Mater Interfaces, 2009, 1: 590

[10] Avnir D, Coradin T, Lev 0, Livage J.J Mater Chem, 2006, 16: 1013
[11] Jiang Y J, Yang D, Zhang L, Li L, Sun Q Y, Zhang Y F, Li J, Jiang Z Y. Dalton Trans, 2008, 31: 4165

[12] Jiang Y J, Yang D, Zhang L, Sun Q Y, Sun X H, Li J, Jiang Z Y. Adv Funct Mater, 2009, 19: 150

[13] Moss D, Nabedryk E, Breton J, Mäntele W. Eur J Biochem, 1990, 187: 565

[14] Luckarift H R, Spain J C, Naik R R, Stone M O. Nat Biotechnol, 2004, 22: 211

[15] Luckarift H R, Dickerson M B, Sandhage K H, Spain J C. Small, 2006, 2: 640

[16] Luckarift H R, Ku B S, Dordick J S, Spain J C. Biotechnol Bioeng, 2007, 98: 701

[17] Ivnitski D, Artyushkova K, Rincón R A, Atanassov P, Luckarift H R, Johnson G R. Small, 2008, 4: 357

[18] Fang Y N, Wu Q Z, Dickerson M B, Cai Y, Shian S, Berrigan J D, Poulsen N, Kröger N, Sandhage K H. Chem Mater, 2009, 21: 5704

[19] Haase N R, Shian S, Sandhage K H, Kröger N. Adv Funct Mater, 2011, 21: 4243

[20] Jan J S, Chuang T H, Chen P J, Teng H. Langmuir, 2011, 27: 2834

[21] Shi J F, Zhang L, Jiang Z Y. ACS Appl Mater Interfaces, 2011, 3: 881

[22] Cui H F, Zhang K, Zhang Y F, Sun Y L, Wang J, Zhang W D, Luong J H T. Biosens bioelectron, 2013, 46: 113

[23] Zhou L Y, Jiang Y J, Gao J, Zhao X Q Ma L, Zhou Q L. Biochem Eng J, 2012, 69: 28

[24] Yu Z H, Su T T, Ren C H, Li F, Xia D G, Cheng S Y. Acta Phys-Chim Sin, 2012, 28: 2867

[25] Lee H U, Park C, Kim S W. Process Biochem, 2012, 47: 1282

[26] Caruso F, Caruso R A, Möhwald H. Science, 1998, 282: 1111

[27] Bradford M M. Anal Biochem, 1976, 72: 248

[28] Chen XY, Huang L M, Li Q Z. J Phys Chem B, 1997, 101: 8460

[29] Li J, Jiang Z Y, Wu H, Zhang L, Long L H, Jiang Y J. Soft Matter, 2010, 6: 542

[30] Rauf S, Ihsan A, Akhtar K, Ghauri M A, Rahman M, Anwar M A, Khalid A M. J Biotechnol, 2006, 121: 351

[31] Cosulich M E, Russo S, Pasquale S, Mariani A. Polymer, 2000, 41: 4951

\section{Graphical Abstract}

Chin. J. Catal., 2013, 34: 1627-1633 doi: 10.1016/S1872-2067(12)60635-4

Biomimetic preparation of organic-inorganic composite microcapsules for glucose oxidase immobilization

Qian Xin, Yanjun Jiang*, Jing Gao*, Liya Zhou, Li Ma, Ying He, Fei Jia Hebei University of Technology; Institute of Process Engineering, Chinese Academy of Sciences

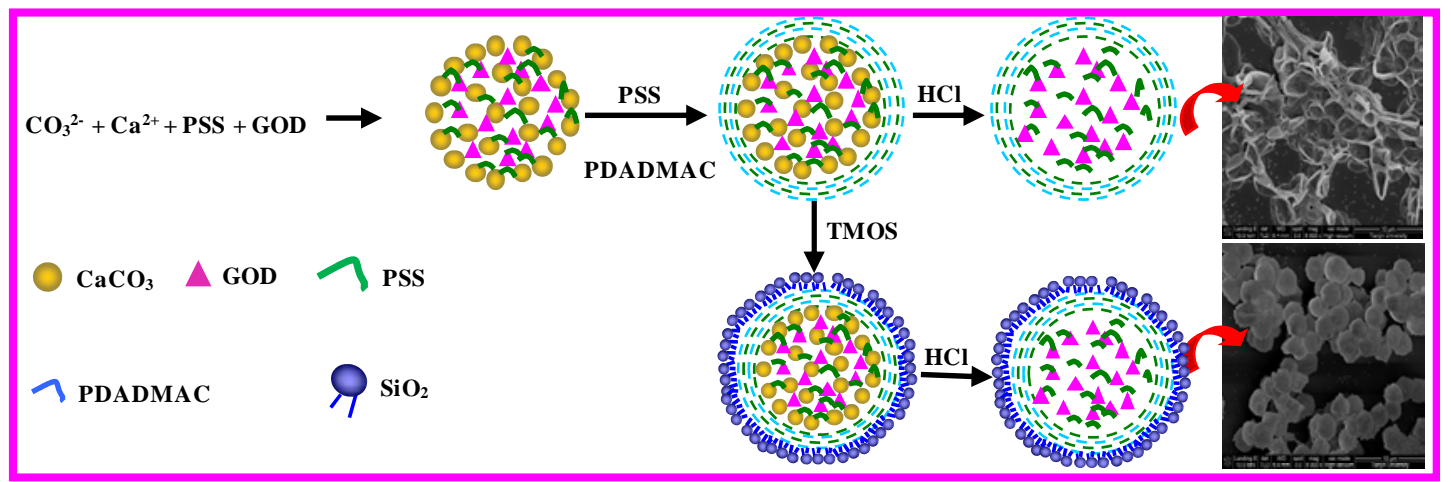

Glucose oxidase (GOD) was immobilized in organic-inorganic composite microcapsules using a combination of layer-by-layer assembly and biomimetic mineralization. The encapsulated GOD exhibited distinct advantages in terms of thermal, $\mathrm{pH}$, and operational stabilities. 


\title{
仿生制备有机-无机复合微囊固定化葡萄糖氧化酶
}

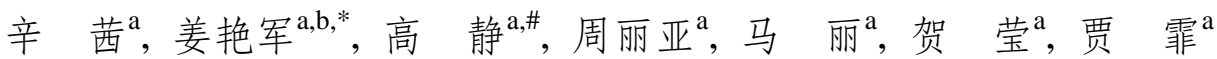 \\ a河北工业大学化工学院, 天津 300130 \\ b 中国科学院过程研究所生化工程国家重点实验室, 北京 100190
}

\begin{abstract}
摘要: 将层层自组装技术与仿生矿化技术相结合, 由聚苯乙烯磺酸钠、聚二甲基二烯丙基氯化铵和二氧化硅成功制备(聚苯乙烯 磺酸钠-聚二甲基二烯丙基氯化铵 $)_{2}$ 二 二氧化硅复合微囊. 采用扫描电子显微镜、红外光谱和热重对微囊的形貌和化学结构进行了 表征. 以该复合微囊作为理想载体固定化葡萄糖氧化酶. 结果表明, 固定于复合微囊中的葡萄糖氧化酶的热稳定性、 $\mathrm{pH}$ 稳定性、 操作稳定性得到了提高; 在最适条件下, 复合微囊固定化葡萄糖氧化酶的酶活回收率为 $72.85 \%$, 米氏常数是游离葡萄糖氧化酶的 2.21倍. 复合微囊在化学/生物催化、药物/基因传递系统和生物传感器应用方面具有一定的潜能.

关键词：复合微囊；层层自组装；仿生矿化；葡萄糖氧化酶

收稿日期: 2013-03-25. 接受日期: 2013-06-19. 出版日期: 2013-08-20.

*通讯联系人. 电话/传真: (022)60204945; 电子信箱: yanjunjiang@hebut.edu.cn

\#通讯联系人. 电话/传真: (022)60204293; 电子信箱: jgao@hebut.edu.cn

基金来源：国家自然科学基金(21006020，21276060，21276062); 河北省应用基础研究计划重点基础研究项目(11965150D); 天津 自然科学基金(13JCYBJC18500); 生化工程国家重点实验室开放课题.

本文的英文电子版由Elsevier出版社在ScienceDirect上出版(http://www.sciencedirect.com/science/journal/18722067).
\end{abstract}

